\title{
Gastric Emphysema: An Etiologic Classification
}

\author{
FAROOQ P. AGHA, M.D. \\ Department of Radiology \\ University of Michigan Hospitals, and Medical Center \\ Ann Arbor, Michigan 48109 USA.
}

\section{INTRODUCTION}

The radiological detection of gas within the wall of the stomach is not diagnostic entity per se but rather a sign of underlying abnormality. Several terms have been applied to this condition including intramural or interstitial gastric emphysema, emphysematous gastritis, gastric pneumatosis, nonbacterial gastric emphysema and pneumatosis cystoides intestinalis. Based on our etiologic understanding, gas accumulating in the wall of the stomach can arise outside the stomach or can be formed within the gastric wall. The terms gastric emphysema and emphysematous gastritis refer to these respective processes. Cystic pneumatosis of the stomach, either isolated or as part of a generalized process of pneumatosis cystoides intestinalis, should be considered a separate entity, the etiology of which is the subject of much conjecture and controversy.

This report deals primarily with gastric emphysema, emphasizing its subclassification into traumatic, obstructive and pulmonary types depending upon the etiology and pathogenesis. The clinical significance of this classification is important from management and prognostic standpoints, where the radiologist may play a significant role. Three cases of gastric emphysema, each of different etiology, are summarized in the following case reports.

Key Words:

Gastric emphysema, emphysematous gastritis, gastric pneumatosis.

Address correspondence and reprints requests to:

Farooq P. Agha, M.D.

Department of Radiology,

Box 13,

University Hospital,

$1405 \mathrm{E}$. Ann St.

Ann Arbor, Mjchigan 48109

\section{CASE REPORTS}

\section{Case 1.}

A 74-year-old man with an inoperable hypopharyngeal carcinoma had a feeding tube gastrostomy in June, 1982 at the Veterans Administration Medical Center, Ann Arbor. He was readmitted in August 1982, because of marked weakness and malfunctioning of the gastrostomy tube.

On physical examination he was very emaciated and malnourished. His blood pressure was $110 / 70$, pulse $80 /$ minute, and respiration 18 /minute. The liver was palpable four fingers breadths below the costal margin. The gastrostomy tube was loose and sagging. Laboratory data revealed a hemoglobin of 10 grams per 100 $\mathrm{ml}$, a hematocrit of 34 , and a WBC of $8000 / \mathrm{Cu}$ $\mathrm{ml}$ with a normal differential count. Urine analysis was normal.

The plain radiograph of the abdomen revealed linear gas collections in the left upper quadrant suggesting intramural gas in the stomach. An upper gastrointestinal examination (Figure 1) using water soluble iodinated contrast material injected through the gastrostomy tube confirmed the presence of linear gas collections located in the wall of the stomach. No free gastric perforation or leakage of contrast material was noted. The gastrostomy tube was sagging from its original position, and its tip was lying partially in the intramural portion of the stomach. The patient underwent surgical adjustment of gastrostomy tube. The stoma around the tube was tightened. Since surgical revision the gastrostomy tube has been functioning well. The gas in the wall of the stomach resolved within two days.

Accepted for publication on 16th March, 1984. 


\section{GASTRIC EMPHYSEMA: AN ETIOLOGIC CLASSIFICATION}

Comment: The gastric emphysema in this patient is of traumatic origin due to a mucosal breech produced by gastrostomy tube insertion. It resolved spontaneously following correction of sagging of the gastrostomy tube.

\section{Case 2.}

A 62-year-old man complaining chiefly of shortness of breath was admitted to the Veterans Administration Medical Center, Ann Arbor in October 1981. He had a long history of chronic obstructive pulmonary disease. He denied chest pain, fever or chills. His past history was noncontributory. He had smoked two packs of cigarettes per day for thirty years.

On examination the patient had a typical emphysematous build and was in moderate respiratory distress. His pulse rate was $100 /$ minute, blood pressure $150 / 90$, respiration 28 /minute and temperature $98^{\circ} \mathrm{F}$. The chest radiograph revealed advanced chronic obstructive pulmonary disease. There was no evidence of pneumonitis, pulmonary neoplasia, mediastinal lesions or cardiac abnormalities. The electrocardiogram showed slight right ventricular enlargement. The biochemical profiles of blood and urine were normal. The patient was treated

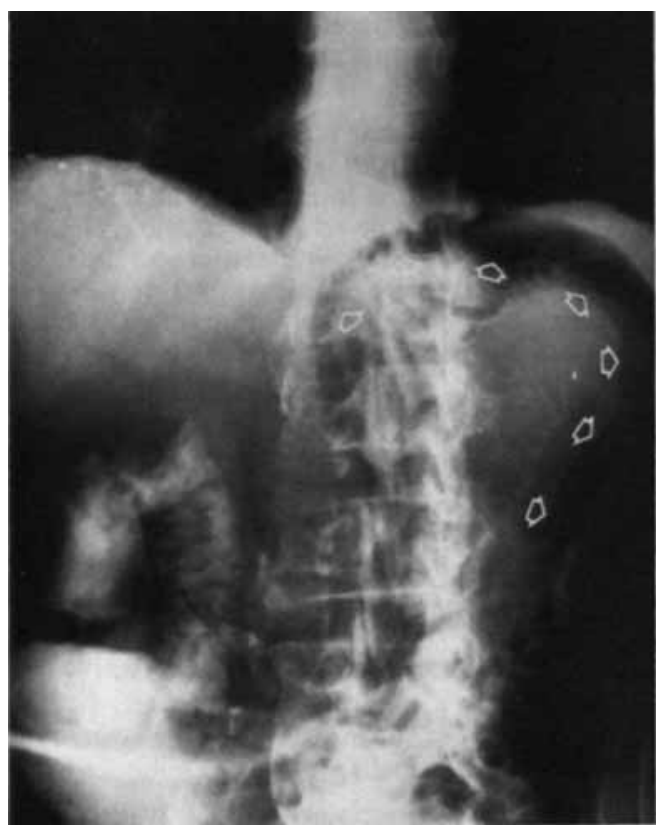

FIGURE 1. - Case 1. Traumatic gastric emphysema. Gastrostomy tube injection with water soluble contrast medium showing linear collection of intramural air outlining the proximal half of the stomach (arrows).

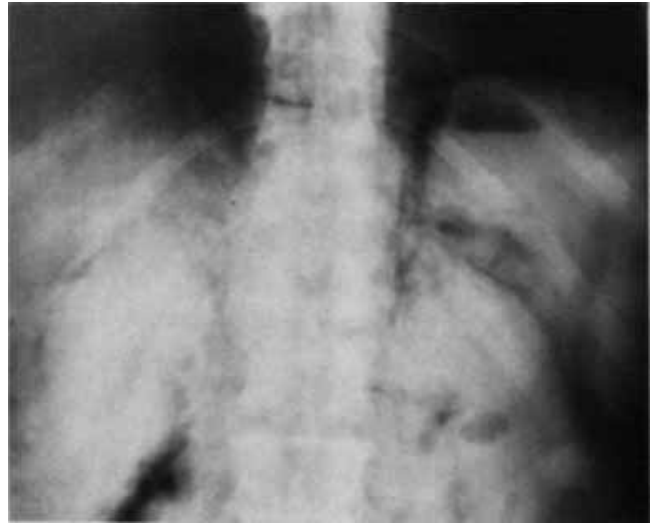

FIGURE 2A

FIGURES 2A \& 2B. - Case 2.Pulmonary gastric emphysema. Supine and lateral projections of the upper $a b$ domen showing extensive retroperitoneal emphysema and gastric emphysema best seen as the lateral projection (arrows) (S - Stomach).

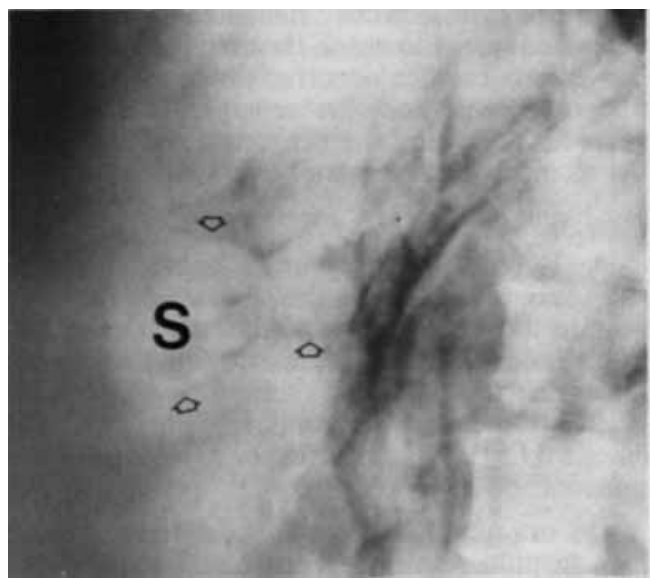

FIGURE 2B

with general supportive measures. His shortness of breath did not improve and he suffered cardiac arrest on the following day. Extensive resuscitative measures revived the patient. On the next day marked emphysema was noted in the neck and mediastinum. Abdominal radiographs (Figure 2) revealed retroperitoneal emphysema with air outlining the gastric wall. The respriatory status of the patient continued to deteriorate and he died two days later.

Comment: These radiographs illustrate an example of the pulmonary origin of gastric emphysema. The air leaking through pulmonary 


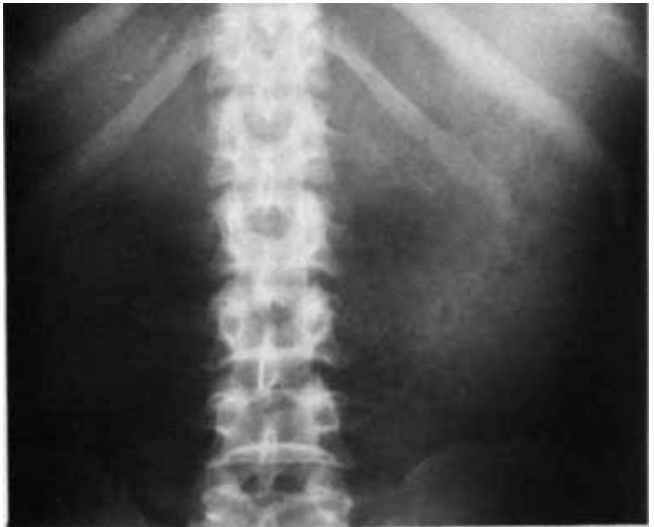

FIGURE 3A. - Case 3. Plain abdominal film showing mottled lucencies in the upper abdomen in the region of the stomach.

alveoli ruptured by extensive mechanical respiratory assistance dissected along the vascular sheaths to reach the mediastinum. Further dissection then occurred down the paraesophageal plane into the retroperitoneum and some air following the peritoneal reflections of the stomach caused gastric emphysema.

\section{Case 3.}

A 37-year-old black man complaining of shortness of breath, and early satiety of three months duration, was admitted to Veterans Administration Medical Center, Ann Arbor in December 1981. He had recently developed epigastric fullness and discomfort with occasional emesis. His past family and social histories were noncontributory.

On examination, he was a cachectic young man in mild respiratory distress. The liver was palpable three fingers breadths below the right costal margin and there was epigastric fullness. The chest radiograph revealed a small left pleural effusion. The abdominal radiograph showed several mottled lucencies in the left upper abdomen (Figure 3A). An upper gastrointestinal series showed an annular obstructing carcinoma of the stomach (Figure 3B). Several nodular lucencies, representing gastric emphysema, were noted in the wall of the stomach. Gastroscopy and biopsy of the antral lesion confirmed poorly differentiated adenocarcinoma of the stomach. A radionuclide liver scan showed diffuse hepatic metastases. The left pleural tap revealed a malignant effusion. Because of the extensive nature of the disease, he received palliative supportive therapy for pain and short-

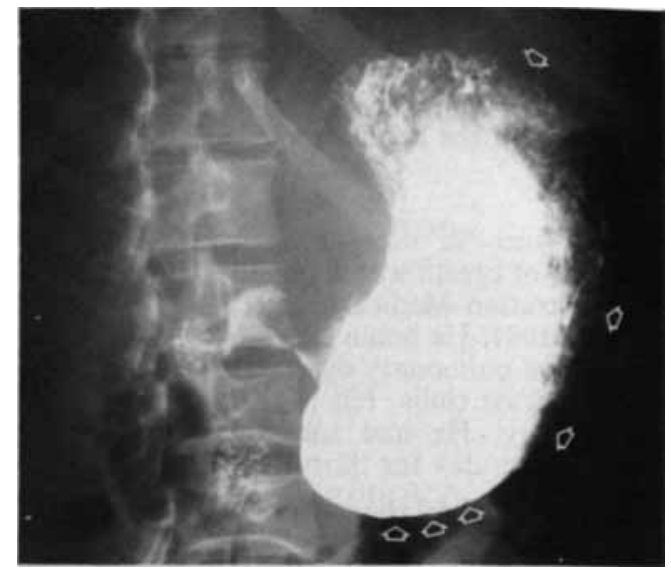

FIGURE 3B. - Case 3. Obstructive gastric emphysema. Upper gastrointestinal series shows an annular partially obstructing carcinoma of the stomach several nodular defects along the contour of the stomach (arrows) represent air in the wall of the stomach.

ness of breath. Chemotherapy was considered and surgery was ruled out. His general condition continued to deteriorate and he died eight days following admission. The autopsy revealed an extensive poorly differentiated obstructing carcinoma of the gastric antrum with widespread metastases.

Comment: This case represents an example of the obstructive type of gastric emphysema. At first sight the mottled lucencies in the left upper abdomen appear to be retained gastric contents. The lack of change in their location and distribution in several projections suggest intramural gastric air. The changes in the upper gastrointestinal contrast examination are subtle.

\section{DISCUSSION}

Gas within the wall of the stomach has been categorized by most authors under three headings:

1. Gastric emphysema (intramural, interstitial or nonbacterial) ${ }^{1-20}$.

2. Emphysematous gastritis (infective or bacterial $)^{21-28}$.

3. Cystic pneumatosis (pneumatosis cystoides intestinalis) ${ }^{29-34}$.

The presence of gas within the wall of the stomach is a sign of an underlying abnormality. Ways by which gas can accumulate within the gastric wall are either by entering from without or by being formed within the wall. Gastric em- 


\section{GASTRIC EMPHYSEMA: AN ETIOLOGIC CLASSIFICATION}

TABLE 1

Gastric Emphysema Cases Reported in the Literature (Total 26 Cases)

\begin{tabular}{|c|c|c|c|}
\hline & Author (Ref,-Year) & Clinical Condition & Comment \\
\hline 1. & $\begin{array}{l}\text { Nitch } \\
(29-1926)\end{array}$ & Carcinoma of stomach & Obstructive gastric emphysema \\
\hline 2. & $\begin{array}{l}\text { Baumann-Schenker } \\
(34-1939)\end{array}$ & $\begin{array}{l}\text { Pyloric obstruction carcinoma } \\
\text { of stomach }\end{array}$ & Obstructive gastric emphysema \\
\hline 3. & $\begin{array}{l}\text { Myhre \& Wilson } \\
\text { (1-1948) }\end{array}$ & Post gastroscopy & Traumatic gastric emphysema \\
\hline 4. & $\begin{array}{l}\text { Myhre \& Wilson } \\
\text { (1-1948) }\end{array}$ & Post gastroscopy & Traumatic gastric emphysema \\
\hline 5. & $\begin{array}{l}\text { Fierst et al } \\
(3-1951)\end{array}$ & Post gastroscopy & Traumatic gastric emphysema \\
\hline 6. & $\begin{array}{l}\text { Cancelmo } \\
(4-1954)\end{array}$ & $\begin{array}{l}\text { Cancer of esophagus } \\
\text { Sever vomiting }\end{array}$ & $\begin{array}{l}\text { Traumatic gastric emphysema } \\
\text { Vomiting producing microtears in } \\
\text { the gastric mucosa }\end{array}$ \\
\hline 7. & $\begin{array}{l}\text { Lumsden } \\
(5-1956)\end{array}$ & $\begin{array}{l}\text { Pyloric obstruction carcinoma } \\
\text { of stomach }\end{array}$ & Obstructive gastric emphysema \\
\hline 8. & $\begin{array}{l}\text { Plachta \& Speer } \\
\text { (6-1957) }\end{array}$ & Pulmonary emphysema & $\begin{array}{l}\text { Gastric emphysema of pulmonary } \\
\text { origin }\end{array}$ \\
\hline 9. & $\begin{array}{l}\text { Plachta \& Speer } \\
(6-1957)\end{array}$ & Pulmonary emphysema & $\begin{array}{l}\text { Gastric emphysema of pulmonary } \\
\text { origin }\end{array}$ \\
\hline 10. & $\begin{array}{l}\text { Plachta \& Speer } \\
(6-1957)\end{array}$ & Pulmonary emphysema & $\begin{array}{l}\text { Gastric emphysema of pulmonary } \\
\text { origin }\end{array}$ \\
\hline 11. & $\begin{array}{l}\text { Plachta \& Speer } \\
(6-1975)\end{array}$ & Pulmonary emphysema & $\begin{array}{l}\text { Gastric emphysema of pulmonary } \\
\text { origin }\end{array}$ \\
\hline 12. & $\begin{array}{l}\text { Ward } \\
(7-1960)\end{array}$ & $\begin{array}{l}\text { Obstructive carcinoma of } \\
\text { stomach }\end{array}$ & Obstructive gastric emphysema \\
\hline 13. & $\begin{array}{l}\text { Druckman } \\
(33-1961)\end{array}$ & $\begin{array}{l}\text { Pyloric obstruction due to } \\
\text { peptic ulcer disease }\end{array}$ & $\begin{array}{l}\text { Pyloroduodenal obstruction } \\
\text { causing obstructive gastric } \\
\text { emphysema. }\end{array}$ \\
\hline 14. & $\begin{array}{l}\text { Key-Butler } \\
(9-1962)\end{array}$ & $\begin{array}{l}\text { Obstruction of duodenum and five } \\
\text { days of persistent vomiting. } \\
\text { Cancer of pancreas }\end{array}$ & $\begin{array}{l}\text { Obstructive gastric emphysema } \\
\text { Persistent severe vomiting } \\
\text { producting microtears in the } \\
\text { gastric mucosa. }\end{array}$ \\
\hline 15 . & $\begin{array}{l}\text { Schoor \& Marcus } \\
(10-1962)\end{array}$ & Duodenal obstruction by gall stone & Obstruction gastric emphysema \\
\hline 16. & $\begin{array}{l}\text { Berdon et al } \\
(11-1964)\end{array}$ & Necrotizing enterocolitis & Loss of mucosal integrity \\
\hline 17. & $\begin{array}{l}\text { Seaman \& Fleming } \\
(14-1967)\end{array}$ & Gastric volvulus & Obstructive gastric emphysema \\
\hline 18. & $\begin{array}{l}\text { Seaman \& Fleming } \\
(14-1967)\end{array}$ & Persistent vomiting & Traumatic gastric emphysema \\
\hline 19. & $\begin{array}{l}\text { Seaman \& Fleming } \\
(14-1967)\end{array}$ & Necrotizing enterocolitis & Loss of mucosal integrity \\
\hline 20. & $\begin{array}{l}\text { Chamberlain } \\
(2-1967)\end{array}$ & Post gastroscopy & Traumatic gastric emphysema \\
\hline 21. & $\begin{array}{l}\text { Siegel } \\
(17-1975)\end{array}$ & Carcinoma of stomach & Obstructive gastric emphysema \\
\hline 22. & $\begin{array}{l}\text { Turnbull } \\
(19-1979)\end{array}$ & $\begin{array}{l}\text { Pyloric obstruction due to } \\
\text { duodenal ulcer }\end{array}$ & Obstructive gastric emphysema \\
\hline 23. & $\begin{array}{l}\text { Kussin } \\
(20-1982)\end{array}$ & Carcinoid obstructing stomach & Obstructive gastric emphysema \\
\hline 24. & $\begin{array}{l}\text { Agha } \\
(\mathrm{P}-1983)^{*}\end{array}$ & Obstructing carcinoma of stomach & Obstructive gastric emphysema \\
\hline 25 . & $\begin{array}{l}\text { Agha } \\
(\text { P-1983)* }\end{array}$ & Sagging tube gastrostomy & Traumatic gastric emphysema \\
\hline 26. & $\begin{array}{l}\text { Agha } \\
\text { (P-1983)* }\end{array}$ & Patient on respirator & Pulmonary gastric emphysema \\
\hline
\end{tabular}

*P: Present Report. 
physema and emphysematous gastritis refer to these processes respectively. Cystic pneumatosis of the stomach, whether isolated finding or part of generalized pneumatosis cystoides intestinalis, should be considered a separate entity. Gastric emphysema refers to a situation in which gas collects in the wall of the stomach without associated infection by gas forming organisms. The radiologic features are characteristic linear streaks of radiolucencies parallel to the border of the stomach, few millimeters in width and separated from the lumen by an area of intervening gastric wall. These streaks do not change in location in different radiographic projections 35,36 . The gas usually collects in the submucosa or subserosa. To date only twenty-six examples of intramural gastric emphysema have been recorded in the literature including three from the present report (Table 1).

Gastric emphysema is a radiographic finding that may result due to a variety of clinical conditions. Depending upon the etiology and pathogenesis, it can be divided into three categories; traumatic, obstructive, or pulmonary.

a) Traumatic gastric emphysema - Myhre and Wilson ${ }^{1}$ studied abdominal films on 119 consecutive patients 24 hours after gastroscopy and found only one case who developed gastric emphysema without gastric perforation. The patient remained asymptomatic. Chamberlain ${ }^{2}$ and Fierst ${ }^{3}$ each added a single case of asymptomatic gastric emphysema following endoscopy. Most recently Katz et al described this finding following fibroptic endoscopy. Because of these reports, the finding of linear streaks of gas within the wall of the stomach is viewed as a benign self-limiting condition. With increasing use, endoscopy it has become the most frequent cause of gastric emphysema ${ }^{16,21}$.

The patient is usually asymptomatic. Microorganisms are not involved. The source of the gas is intraluminal air. It is probably related to direct transmural diffusion of gas from the airdistended stomach. The clinical course is benign, and spontaneous resolution is the rule. No treatment is required. When mucosal integrity is impaired following gastric biopsy or gastrostomy, transient localized intramural air may be seen. Breeching of mucosal integrity and partial intramural location of the tip of the gastrostomy tube are obvious explanations of gastric emphysema in Case 1.

b) Obstructive - Interstitial gastric emphysema is usually associated with chronic peptic ulcer producing partial gastric outlet obstruction. Lumsden $^{5}$ described the first case associated with obstructive carcinoma of the stomach. Increased intragastric pressure and a diseased mucosa associated with gastric outlet obstruction due to carcinoma or peptic ulcer permits intraluminal air to enter the wall of the stomach. Only eleven examples of gastric emphysema due to obstructing lesions have been recorded $^{7}, 9,10,12,14,17,29,33,34$ including one case from this report. Gastric obstruction by gastric volvulus, duodenal obstruction due to gall stone and to pancreatic carcinoma have been reported as causes of gastric emphysema. In obstructive gastric emphysema, the gas enters the wall through a breech in the mucosa associated with increased intragastric pressure, and vomiting. With gastric obstruction associated with a normal mucosa such as gastric volvulus and gallstones causing duodenal obstruction, there are other possible routes that allow passage of gas into the submucosa. These include the areas around the vascular sheaths ${ }^{34}$ and perilymphatic areas ${ }^{2}$. The linear collection of air is usually progressive and may even produce pneumoperitoneum by passage of the gas along the peritoneal reflections of the stomach into the gastrohepatic and phrenoesophageal ligaments or the greater omentum. Relief of obstruction results in resolution of gastric emphysema within a few days.

c) Pulmonary type - This is the rarest type of gastric emphysema. Only five cases of pulmonary gastric emphysema have been recorded, four reported by Plachta and Speer ${ }^{6}$ and one in the present report. The four cases reported by Plachta and Speer were due to bullous emphysema. Air from ruptured bullae dissected along the vascular sheaths and reached the paraoesophageal area followed by a gradual downward dissection into the submucosa of the stomach leading to gastric emphysema. All four patients had no abdominal symptoms and no radiographs of the abdomen were obtained. The diagnosis of esophageal and gastric emphysema was made at autopsy. In our case marked emphysema of the mediastinum and retroperitoneum developed due to extensive resuscitative efforts. Some air also dissected into the wall of the stomach producing gastric emphysema.

The subclassification of gastric emphysema on the basis of its pathogenesis into traumatic, obstructive and pulmonary types has definite clinical and prognostic implications. These features are summarized in Table 2 .

\section{ABSTRACT}

Gas within the wall of the stomach is a rare 


\section{GASTRIC EMPHYSEMA: AN ETIOLOGIC CLASSIFICATION}

TABLE 2

Classification of Gastric Emphysema

\begin{tabular}{|c|c|c|c|c|}
\hline Types & $\begin{array}{l}\text { Clinical Signs } \\
\text { and Symptoms }\end{array}$ & $\begin{array}{l}\text { Etiology and } \\
\text { Pathogenesis }\end{array}$ & Lab Culture & $\begin{array}{l}\text { Natural History } \\
\text { and Therapy }\end{array}$ \\
\hline Traumatic & None & $\begin{array}{l}\text { Distension of lumen } \\
\text { with transmural } \\
\text { diffusion of gas through } \\
\text { micro mucosal tears }\end{array}$ & Negative & $\begin{array}{l}\text { Spontaneous remission. } \\
\text { Self limiting no } \\
\text { treatment }\end{array}$ \\
\hline Obstructive & $\begin{array}{l}\text { Severe vomiting with } \\
\text { obstructive symptoms }\end{array}$ & $\begin{array}{l}\text { Distended stomach with } \\
\text { increased intragastric } \\
\text { pressure and breech of } \\
\text { mucosal integrity }\end{array}$ & $\begin{array}{l}\text { Usually } \\
\text { negative }\end{array}$ & $\begin{array}{l}\text { Progressive treatment of } \\
\text { of underlying disease } \\
\text { causing gastric or } \\
\text { duodenal obstruction }\end{array}$ \\
\hline Pulmonary & $\begin{array}{l}\text { None related to gastric } \\
\text { emphysema. } \\
\text { Pulmonary symptoms } \\
\text { present due to chronic } \\
\text { obstructive pulmonary } \\
\text { disease }\end{array}$ & $\begin{array}{l}\text { Rupture of pulmonary } \\
\text { alveoli or emphysema- } \\
\text { tous blebs causing } \\
\text { mediastinal emphysema } \\
\text { with dissection of air } \\
\text { into neck, retro- } \\
\text { peritoneum and along } \\
\text { peritoneal reflection of } \\
\text { the stomach }\end{array}$ & Negative & $\begin{array}{l}\text { Self limiting. } \\
\text { Treatment directed } \\
\text { to pulmonary problem. }\end{array}$ \\
\hline
\end{tabular}

radiologic finding. The stomach has been the least often reported site of intramural gas in the hollow viscera. Based on etiology, gas in the wall of the stomach can be classified as either gastric emphysema or emphysematous gastritis. Gastric emphysema may be classified into traumatic, pulmonary or obstructive types depending upon the mechanism and pathogenesis. Three cases of gastric emphysema, each of different etiology, are presented to emphasize the subclassification of gastric emphysema. The clinical and prognostic significance of this classification is emphasized.

\section{REFERENCES}

1. Myhre J and Wilson JA. Study on occurrence of pneumoperitoneum after gastroscopy and observance of interstitial emphysema of stomach. Gastroenterology 1948; 11 : 115-119.

2. Chamberlain DT. Pneumoperitoneum following gastroscopy apparently without perforation: Report of a case. N Engl J Med 1947; 237 : 843-845.

3. Fierst SM, Robinson HM and Lasagna L. Interstitial gastric emphysema following gastroscopy: Its relations to syndrome of pneumoperitoneum and generalized emphysema with no evident perforation. Ann Int Med $1951 ; 34: 1202-1212$.

4. Cancelmo I. Interstitial gastric emphysema with report of a case. Radiology $1954 ; 63: 81-83$.

5. Lumsden $K$. Radiologic demonstration of gas in the stomach wall. Brit I Radiol 1956; $29: 596-600$.

6. Plachta A and Speer F. Non-bacterial gastric emphysema - a review of the literature and report of a case. Amer J Gastroenterol 1957; $28: 460-465$.

7. Ward P. Interstitial gastric emphysema. Brit $J$ Radiol $1960 ; 33: 458-459$.
8. Plachta A and Speer F. Mechanism of non-bacterial gastric emphysema. Gastroenterology 1961; 40 : 248-252.

9. Kay Butler J. A case of interstitial gastric emphysema. Brit J Surg 1962; 50 : 99-101.

10. Schoor $\mathrm{S}$ and Marcus $M$. Intramural gastric emphysema. Brit J Radiol 1962; 35 : 641-644.

11. Berdon WE, Grossman H, Baker DH, Mizrahi A, Barlow $\mathbf{O}$ and Blanc WA. Necrotizing enterocolitis in the premature infant. Radiology $1964 ; 83: 879-887$.

12. Colquhoun J. Intramural gas in hollow viscera. Clin Radiol 1965; $16: 71-86$.

13. Smith T. Emphysematous gastritis associated with adenocarcinoma of the stomach. Amer J Diag Dis 1966; $11: 341-345$.

14. Seaman WB and Flemming RJ. Intramural gastric emphysema. Amer J Roentgenol 1967; $101: 431-436$.

15. Berens $\mathrm{S}$, Moskowitz $\mathrm{H}$ and Mellins $\mathrm{HZ}$. Air within the wall of the stomach. Amer J Roentgenol 1968; 103 : 310-313.

16. Katz D, Cano $R$ and Antonelle N. Benign air dissection of the esophagus and stomach at fibresophagoscopy. Gastrointest Endoscopy 1972; $19: 72-74$.

17. Siegel $\mathrm{H}$. Air or gas within the wall of the stomach. Amer J Gastroenterol 1975; $64: 490-493$.

18. Martin $\mathbf{W}$, Nagar $\mathbf{N}$, Diner $\mathbf{W}$ and Tester $C$. Benign retroperitoneal emphysema associated with upper gastrointestinal endoscopy. Arch Int Med 1978; 138 : 759-761.

19. Tumbull AR and Mitchell RC. Interstitial emphysema of the stomach. Brit J Surg 1979; 66:350-351.

20. Kussin SZ, Henry C, Navarro $C$, Stensen $W$ and Clair DJ. Gas within the wall of the stomach. Report of a case and review of the literature. Digest Dis Sci 1982; 27 : 949-954.

21. Martin J and Stabin S. Phlegmonous gastritis. Ann Surg 1928; $87: 848$. 


\section{F.P. AGHA}

22. Welch $\mathrm{C}$ and Jones. Emphysematous gastritis. $\mathrm{N}$ Engl $\mathrm{J}$ Med 1947; $237: 983$.

23. Henry G. Emphysematous gastritis. Amer J Roentgenol 1952; $68: 15-18$.

24. Ween H. Emphysematous gastritis. Amer J Roentgenol 1946; $55: 588-593$.

25. Gonzalez L, Schowengerdt $C$, Skinner $H$ and Lynch $P$. Emphysematous gastritis. Surg Gynecol Obstet 1963; $116: 79-87$

26. Hans S, Collis $L$ and Petrany Z. Emphysematous gastritis. I Amer Med Assoc 1965; 192 : 222-224.

27. Meyers $\mathrm{HI}$ and Parker JJ. Emphysematous gastritis. Radiology $1967 ; 89: 426-431$.

28. Sawyer $R$, Saywer $K$ and List J. Infectious emphysema of the gastrointestinal tract in the adult. Amer J Surg $1970 ; 120: 579-583$.

29. Nitch C. Cystic pneurnatosis of the intestinal tract. Brit J Surg 1924; $11: 714-734$.
30. Lerner $\mathbf{H}$ and Gazin A. Pneumatosis intestinalis - its roentgenologic diagnosis. Amer J Roentgenol 1946; 56 : 464-469.

31. Koss L. Abdominal gas cysts. Arch Pathol 1952; 55 : 523-529.

32. Keyting W, McCarver R, Kovarik $\mathbf{J}$ and Daywitt A. Pneumatosis intestinalis: A new concept. Radiology 1961; 76:731-741.

33. Druckman A, Schwartz A, Rabinovic N and Feuchtwanger M. Pneumatosis of the intestines. Amer J Roentgenol 1961; 86 : 911-919.

34. Baumann-Schenker $\mathbf{R}$. Uber pneumatosis cystoides ventriculi et jejuni. Acta Radiol 1962; 30 : 365-373.

35. Nelson SW. Extraluminal gas collections due to diseases of the gastrointestinal tract. Amer J Roentgenol 1972; $115: 225-248$.

36. Meyers MA, Ghahremani GG, Clement JL Jr and Goodman K. Pneumatosis intestinalis gastrointestional. Radiology 1977; 2 : 91-105. 